I. Sheviakov ${ }^{1}$, V. Larin ${ }^{1}$, E. Kazakov ${ }^{2}$, Ahmed Abdalla ${ }^{2}$

${ }^{1}$ Ivan Kozhedub Kharkiv National Air Force University, Kharkiv

${ }^{2}$ Flying Akademy of the National Aviation University, Kropyvnytskyy

\title{
THE VIDEO PROCESSING FEATURES RESEARCH IN COMPUTER SYSTEMS AND SPECIAL PURPOSE NETWORKS
}

For a typical low complexity video sequence, the weight of each P-frame in the stream is approximately three times smaller than the I-frame weight. However, taking into account the number of P-frames in the group, they make the main contribution to the total video data amount. Therefore, the possibility of upgrading coding methods for Pframes is considered on preliminary blocks' type identification with the subsequent formation of block code structures. As the correlation coefficient between adjacent frames increases, the compression ratio of the differentialrepresented frame's binary mask increases. The compression ratio of the differential-represented frame's binary mask varies from 3 to 21 depending on the correlation coefficient between adjacent frames. The most preferable method for constructing the compact representation technology of the binary masks of frames represented in a differential form is the approach. This is based on the identification and description of the lengths of one-dimensional binary series. A binary series is a consecutive binary elements sequence with the same value. In this case, sequences of identical binary elements are replaced by their lengths.

Keywords: image, compression, frame, element, level, redundancy, technology.

\section{Introduction}

Problem statement. The main difficulty in working with the video is large volumes of transmitted information. Video format $720 \times 576$ pixels 25 frames per second in the RGB system requires a data stream of about 240 Mbit / s. This makes it necessary to use various compression technologies. However, traditional image compression algorithms are oriented to individual frames. They do not save the situation, because even when the stream is reduced by 10 times, it is quite large, which does not allow to fully adapt to the dynamically changing characteristics of the data transmission network [1]. It has been analyzed the predicted frames processing in the MPEG standard and its drawbacks has found during compressing video data. For a typical low complexity video sequence, the weight of each I-frame in the stream is approximately three times bigger than the P-frame weight [2]. However, taking into account the number of Pframes in the group, they make the main contribution to the total video data amount. Therefore, need to upgrade coding methods for P-frames are considered on preliminary blocks' type identification with the subsequent formation of block code structures.

Analysis of the last publications. A lot of researchers have compared features of compressed representation. A comparison of international standards for original image fragment was made in [3] and in this case they have thoroughly investigated the compression ratio of all the well-known compression methods available at that time. However, the comparison in [4] does not deal with analysis of the latest elimination of video image redundancy. Another issue is that consideration is only given to original image fragment.

In [5], the compression ratio and execution time of the compression methods was investigated. Moreover, they investigated the efficiency of compression methods based only on textual data and staticall images. Dynamic components of images are very different from the dynamic images in a differential-represented frame scenario. Another study on the comparison of compression methods was conducted in [6]. They applied many compression standards and some compression programs to the elimination of spatial and temporal redundancy. Such frames (with allowance for correction for motion compensation) compress the codec. They are more than 99\% in the stream (the amplitudes are small, the image is almost uniform). In order to meet the necessary requirements and increase the flexibility of the algorithm, as well, as to achieve the required compression ratio, 3 types of frames are applied to video processing. The basis of the standard video sequence are I-frames (Initial), they are usually allocated with a fixed interval, for example, twice per second (every 12, 15 or 30 frames). Compression of reference frames is performed only with the use of intraframe prediction, i.e. eliminates spatial redundancy. Such frames in the video stream are compressed lesser.

An early effort in elimination of video image redundancy has been performed in [7]. Structural redundancy is the result of the features of the decomposition's standard or, in other words, the transformation of an image into a digital signal. For example, the elements of the signal, that are constant in form, are periodically 
transmitted: blanking pulses of lines and fields.

A spectral redundancy happens as a result of an excessively high sampling frequency. In particular, the received orthogonal video image sampling frame is generally not optimal in the frequency space was proposed in [8].

Using the interpolation and resampling of certain selected groups of video signal samples, it is possible, in principle, to modify the spectral composition and reduce the sampling frequency, is not used.

To ensure the timely delivery of video information resources, it is necessary to take into account the highspeed capabilities of communication channels. To do this, data compression algorithms are used. Approaches to creating methods of compact representation can be divided into three classes depending on the requirements for the quality of reconstructed images. These three methods have been best described in [9].

The research aims and objectives. The aim of article is to research the video processing features research in computer systems and special purpose networks. The objectives of article are the video processing features research in computer systems and special purpose networks and to justification of the significance of predicted P-frames for processing motion images in the technology of compression of transformed images.

\section{Statement of basic materials}

The basis of all compression algorithms is the elimination of video image redundancy. There are several types of redundancy [10]:

1. Structural redundancy is the result of the features of the decomposition's standard or, in other words, the transformation of an image into a digital signal. For example, the elements of the signal, that are constant in form, are periodically transmitted: blanking pulses of lines and fields. In a digital video signal, it is not necessary to transmit these pulses through a communication channel, because they can be reconstructed in the decoder by reference synchronization signals. Elimination of the digital video signal of blanking pulses of lines and fields reduces the video data transmission speed by approximately $23 \%$.

2. Spectral redundancy happens as a result of an excessively high sampling frequency. In particular, the received orthogonal video image sampling frame is generally not optimal in the frequency space. Using the interpolation and resampling of certain selected groups of video signal samples, it is possible, in principle, to modify the spectral composition and reduce the sampling frequency. Such processing is usually irreversible and, as a rule, leads to a certain decrease in the quality of the restored TV image.

These two types of redundancy are taken into account, when forming a video sequence. The overwhelming majority of video compression algorithms are data loss algorithms that use the following types of redundancy, when compressing.

3. Redundancy in perception or psychophysical are caused by the peculiarity of the human image perception system.

For example, the human vision system is not sensitive to very high or very low spatial frequencies. Therefore, to eliminate such redundancy, special methods of sub-filtering and quantization are used, which eliminate inconspicuous details for the human eye.

4. Statistical redundancy is based on the similarity of the adjacent elements' values of the matrix or frame row. To reduce it, statistical codes are used, while video processing uses mostly Huffman code or arithmetic coding.

5. Temporary redundancy or similarity between frames is based on the fact, that at a speed of 25 frames per second, as a rule, adjacent frames change insignificantly. In order to eliminate temporal redundancy, the most common block compensation is the motion, which is a kind of predictive coding.

6. Spatial redundancy is a small change in the color of an image in neighboring pixels. In order to reduce spatial redundancy, encoding with conversion and predictive coding are used.

The greatest attention, in the formation of a compressed video stream, is given to the elimination of spatial and temporal redundancy.

Since the two neighboring frames in most cases differ slightly from each other, as shown in Fig. 1, which allows to transmit not the complete information about the next frame, but only the part where the changes occurred (Fig. 2) [11].
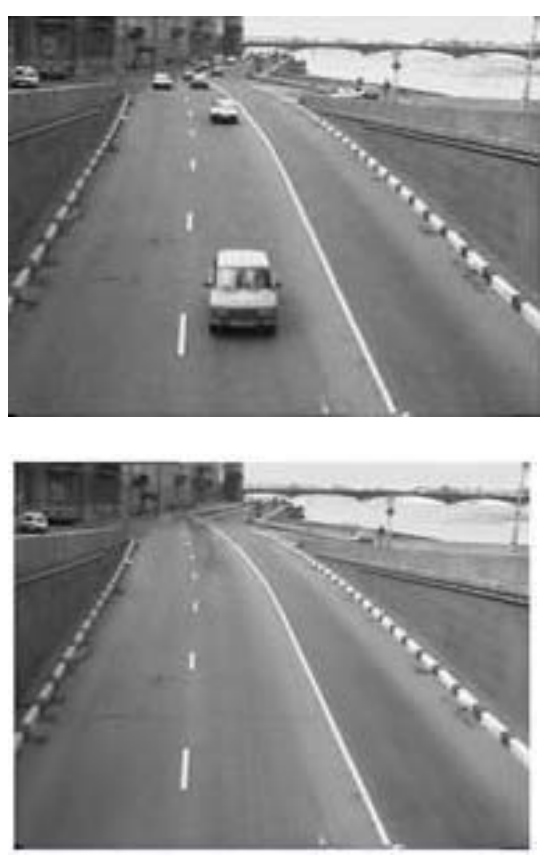

Fig. 1. Neighboring frames from test sequence, block sizes $16 \times 16-4 \times 4$ 


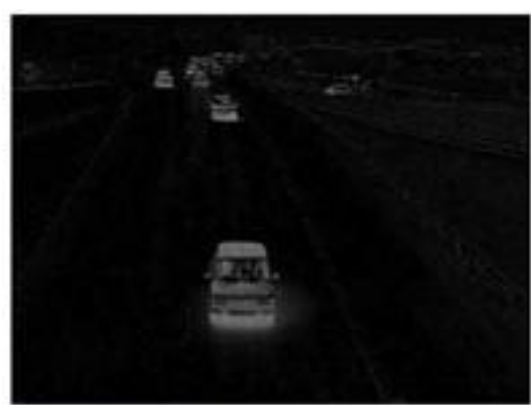

Fig. 2. The inter-frame difference

In order to meet the necessary requirements and increase the flexibility of the algorithm, as well, as to achieve the required compression ratio, 3 types of frames are applied to video processing (Fig. 3).

The basis of the standard video sequence are Iframes (Initial), they are usually allocated with a fixed interval, for example, twice per second (every 12, 15 or 30 frames). Compression of reference frames is performed only with the use of intraframe prediction, i.e. eliminates spatial redundancy. Such frames in the video stream are compressed lesser.

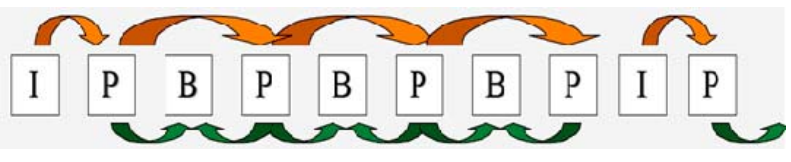

Fig. 3. Frame types and their sequence

Each I-frame is divided into independent macroblocks, inside of which DCTs are performed for blocks [12]. According to the obtained matrix of the spectrum, its truncation occurs (weighting of elements, quantization). Then, the data is linearized and the subsequent statistical compression is performed, and the received packet is inserted directly into the stream. The last measure provides quick access to the keyframe.

P-coding (predicted) is performed with a using motion compensation algorithms and inter-frame prediction forward over previous I or P frames until a new object appears in the block. Once it is detected, the transition to the algorithms used to encode the I-frames, i.e., intra-frame prediction, again occurs. In such frames, besides temporal redundancy, temporary redundancy is also eliminated. With respect to the base P-frames are compressed more strongly by using the fact of the similarity of neighboring frames in the video sequence. Thus, any P-frame can be recovered with the help of the previous I-frame, i.e., in the transmission of the Pframe, only that portion of the image in which changes are present relative to the previous reference frame is transmitted.

Depending on the encoder, P-frames are allocated either at a fixed frequency (that each I- or P-frame is surrounded by two B-frames, for example,
IBBPBВРВВРВВIB ...), or automatically (by the complexity of the video sequence). For a typical video sequence of low complexity, the weight of each P-frame in the stream is approximately three times smaller than the weight of the I-frame. Of course, if we are dealing with dynamic scenes or with a stream of high complexity (say, moving macroblocks so much that their prediction is difficult), then the weight of the P-frames approaches the weight of the key ones.

B-frames are derived from the nearest P- or Iframes. These frames consist exclusively of the predicted macroblocks. These frames are obtained as a result of "interpolation", bidirectional prediction. During playback, the left-most sequence of B-frames is predicted with respect to the nearest (left) I- or P-frame, on the right, the sequence of B-frames (after direct prediction) undergoes forward prediction error correction with respect to the nearest (right) P- or I-frame. When encoding, from frames determined as $\mathrm{B}$, in fact only the matrix of coordinates of the motion vectors is obtained as a result of the analysis of macroblocks motion remains. Thus, for most variants of the low complexity video sequence, the weight of the B-frame in the data stream does not exceed the weight of the P-frame by more than 2 times.

The maximum compression ratio is provided in Btype frames. However, such algorithms are the most resource intensive, which, in case of working with streaming, can lead to significant time delays in data transmission systems. Therefore, only the first two types of frames are possible.

The entire pipeline of transformations of the video sequence can be represented with the help of the following items:

1) preparation of macroblocks. For each macroblock, it is determined how it will be compressed. In Iframes, all macroblocks are compressed independently. In P-frames, the block either contracts independently, or represents a difference with one of the macroblocks in the previous reference frame referred to by the P-frame;

2) the translation of the macroblock into the color space of $\mathrm{YCbCr}$. The getting of the right number of matrices $8 \times 8$;

3) for P and B blocks, the difference is calculated with the corresponding macroblock in the reference frame or encoding with prediction;

4) the transformation of blocks into DCT matrices or wavelet transforms [13];

5) the quantization;

6) zigzag scanning;

7) the group coding;

8) statistical lossless compression (Huffman coding or arithmetic).

When decoding, the entire container of conversions is repeated in the reverse order.

Manipulation of the reconstruction quality and the 
processing time of the video stream is achieved at the following stages:

- step 1. Conversion to color space [14]. Transformation features: when changing to the $\mathrm{YCbCr}$ color space, the chrominance components $(\mathrm{Cb}$ and $\mathrm{Cr})$ containing high-frequency color information (to which the human eye is less sensitive) can be partially discarded and, thereby, the number of pixels taken into account for chroma channels decreases, which leads to increasing the compression ratio. At the same time, the discarding some of the information - the quality of the restored image is reduced;

- stage 2. Segmentation of the image. Segmentation simplifies the buffering of data for transmission over a communication channel. The technology of encoding video frames supports three types of images segmentation: simple, pyramidal and combined (Fig. 4).

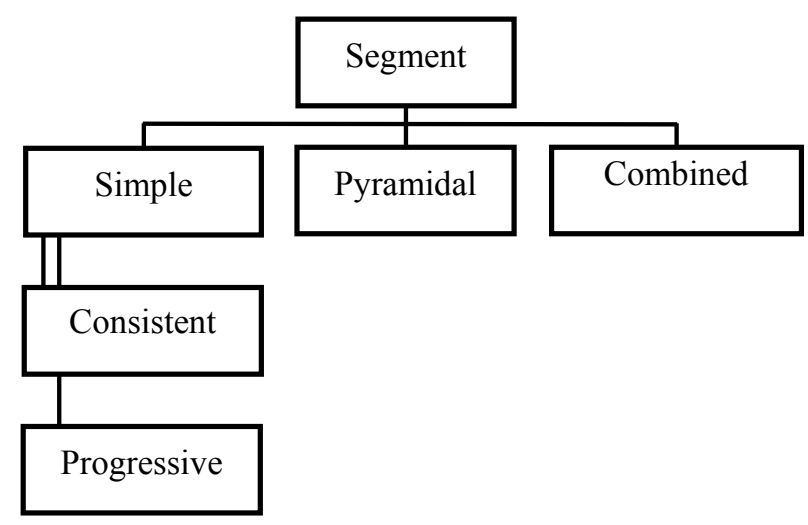

Fig. 4. The types of image segmentation

Stage 3. DCT. The time required to calculate each element of the DCT matrix strongly depends on its size through the use of two nested cycles. In the table. 3.1 shows the data on the number of operations (execution time) DCT for frames of different sizes, taking into account the brightness of the components, the size of the block $8 \cdot 8$.

Depending on the type of segmentation, up to half of the required information can be lost, which leads to a significant reduction in data volumes, while reducing the size of the segment increases the processing speed, increases the distortion in the resulting image.

The time required to calculate each element of the DCT matrix depends strongly on its size, since two nested loops are used, the calculation time is $\mathrm{N} \times \mathrm{N}$ operations. In Table. 1 shows the number of operations (execution time) of the DCT for frames of different sizes, taking into account the brightness components, the block size is $8 \times 8$.

Stage 4 . The quantization.

Quantization is the division of the working matrix into a quantization matrix element by element.
Table 1

The dependence of the number of machine operations on the frame size

\begin{tabular}{|c|c|c|}
\hline Frame's size & $\begin{array}{c}\text { The number of } \\
\text { arithmetical } \\
\text { operations per } \\
\text { one transfor- } \\
\text { mant }\end{array}$ & $\begin{array}{c}\text { The number of } \\
\text { arithmetical op- } \\
\text { erations with ac- } \\
\text { counting of all } \\
\text { transformants }\end{array}$ \\
\hline $512 \times 512$ & 4194304 & 12582912 \\
\hline $800 \times 600$ & 7680000 & 23040000 \\
\hline $1024 \times 768$ & 12582912 & 37748736 \\
\hline
\end{tabular}

Features inherent in the quantization stage: this step sets the compression ratio, the largest loss of information occurs; setting a quantization matrix with large coefficients, the result is getting more zeros (discard some information), therefore, let's set a higher compression ratio; in the JPEG format, the recommended quantization matrixes are constructed by the experimental method are included, the matrixes for greater or smaller compression ratios are obtained by multiplying the original matrix by a certain number QF (quality factor); at large values of the coefficient $\mathrm{QF}$, the losses at low frequencies can be so great that the image decays into squares of $8 \times 8$; losses in high frequencies can appear in the "Gibbs effect".

Stage 5. Encoding.

Due to the use of statistical coding methods (the Huffman algorithm and arithmetic coding), the following drawbacks appear:

- the complexity increasing of software and technical implementation in connection with the need to synchronize and mark uneven code combinations;

- difficulties in the parallel implementation of statistical codes;

- the increase in the number of operations for calculating statistics, building code tables and organizing a double pass on the data being processed;

- the number of encoding operations may exceed the number of operations for performing transformations (for modes providing high quality of the image);

- when recovering, the whole fragment will be restored only after recoding all uneven codewords;

- the need to store code tables and separating markers that reduce the compression rate for Huffman codes;

- for small lengths of zero chains, the uniform distribution of individual elements is characteristic and therefore statistical coding will not provide additional compression of the transformant;

- low noise immunity, both the code lengths of the series, and statistical codes to errors in communication channels;

- increased processing time, especially for medium- and heavily saturated images. 


\section{Justification of the significance of predicted P-frames}

When forming a standard video sequence, a group of frames may constitute either a fixed set of one reference I frame and 11, 14 or 29 P- and B-type frames, or be selectively adaptable depending on the complexity of the video sequence. Therefore, in order to further modernize the methods of coding and control, it is necessary first of all to determine the type of frames having the greatest influence on the total volume of the compressed video sequence. In order to do this, let's make a comparative assessment of the mechanism for processing all types of frames.

I-frames are usually allocated at a fixed interval, for example, twice per second (every 12, 15 or 30 frames). Each I-frame is divided into independent macroblocks, inside of which for 6 or 5 (depending on the YUV model: 4: 2: 2 or 4: 2: 0), the blocks are DCT. By obtaining the matrix of the spectrum, its truncation (weighting of elements, quantization) occurs, while the rate of increase of the quantization's value matrix element (for MPEG-1 and MPEG-2) or the value of all matrix elements (for H.264) will be set, depending on the encoder, and the weighing process itself will be, as in JPEG, in integer division (with the least significant digit error) of the elements of the spectrum matrix into the corresponding elements of the quantization matrix. Then, the data is linearized and the subsequent statistical compression is performed, and the received packet is inserted directly into the stream. The last measure provides quick access to the keyframe.

$\mathrm{P}$-frames actually contain changes relative to the previous I- or P-frame. Depending on the encoder, Pframes are allocated either at a fixed frequency (so that each I- or P-frame is surrounded by two B-frames, for example, IBBPBBPBBPBBIB ...), or automatically (by the complexity of the video sequence). All macroblocks for DCT in these frames include a small number of independent (not predictable), the main part of the frame is made up of the predicted macroblocks. When playing (also approximately), in order to restore the P-frame, it is necessary to restore all previous P-frames and the nearest preceding I-frame. The result of the encoding of each P-frame is also subjected to processing by the statistical compression algorithm and inserted into the stream separately from the I-frames and other P-frames. This is also related to the need for fast transitions to an arbitrary frame, and also this is necessary when rearranging the sequence of frames in the stream. For a typical video sequence of low complexity, the weight of each P-frame in the stream is approximately three times smaller than the weight of the I-frame. Of course, with dynamic scenes or a high complexity stream (for example, there are so many moving macroblocks that their prediction is difficult), the weight of the P-frames approaches the weight of the key ones.
B-frames are derived from the nearest P- or Iframes. These frames consist exclusively of the predicted macroblocks. These frames are obtained as a result of "interpolation", bidirectional prediction. During playback, the left-most sequence of B-frames is predicted with respect to the nearest (left) I- or P-frame, on the right, the sequence of B-frames (after direct prediction) undergoes forward prediction error correction with respect to the nearest (right) $\mathrm{P}$ - or I-frame. When encoding, from frames determined as B, in fact only the coordinates matrix of the motion vectors is obtained as a result of the analysis of the macroblocks motion remains. Thus, for most variants of the video sequence of low complexity, the weight of the B-frame in the data stream does not exceed the weight of the P-frame by more than 2 times. Since B-frames are the largest number, algorithms for compressing not too dynamic scenes are much more efficient than algorithms, where all frames are interpreted as independent. In a stream, Bframes are stored separately from P- and I-frames.

An important feature of the processing method the MPEG standard's video sequence is that frames cease to be independent: it is impossible to reconstruct P- and Bframes without a key I-frame. This circumstance imposes the condition of inseparability on frames within a group of one key frame (Fig. 2). In addition, in the standards of streaming video transmission after processing by the compression algorithm, the frame data is not supplied in the order, that they should be reproduced, but in one that is convenient for fast stream decoding.

First of all, I-frames are needed for reconstruction. That if you pass the first keyframe, then the second Iframe will only be needed to restore all the frames of the second group and the last two B-frames of the first group, i.e. just transmit the first I-frame.

When the I-frame is restored, P-frames will be needed, but again, not all at once - it will be enough to transfer and restore only the first P-frame to start decoding the first B-frame. This completes the first cycle, after which the first three frames are arranged in the stream in the same way as the table shows. Next, you need to transfer and restore the second P-frame, which depends on the second, third and fourth B-frames, then it will be possible to transfer these B-frames for recovery, etc. As a result, in order to mount the video sequence, it is necessary to reorder the sequence of frames, and it is possible to cut and stitch fragments exclusively without splitting freely separated groups located between two I-frames and including these Iframes.

Despite the fact that the largest frame volume has the reference I-frames as shown in Fig. 5, the video sequence consists predominantly of $\mathrm{P}$ and $\mathrm{B}$ frames, as a result, the P-frames have the greatest impact on the total amount of transmitted traffic. 


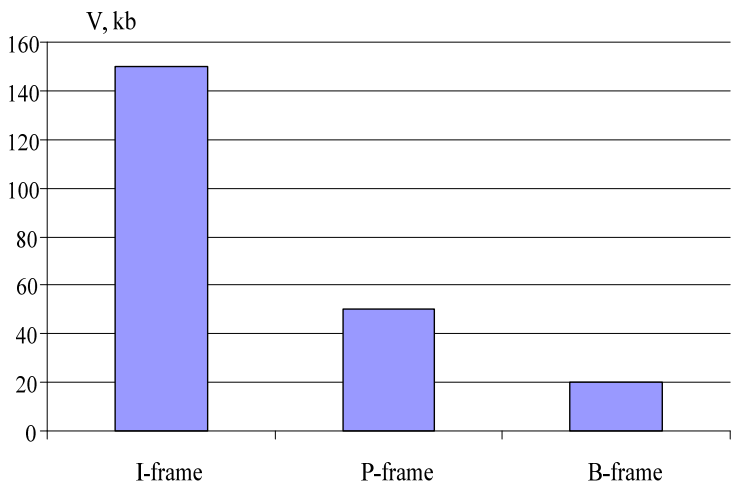

Fig. 5. The ratio of the volumes of I-, P-, B-frames.

Also, taking into account the fact that the possibilities for compressing the reference I-frames are limited, in consequence of the need to provide them with a sufficient level of quality, to further increase the level of the video data compression, we will consider in more detail the process of processing the transformed P-type frames.

\section{Conclusions}

1. As a result of research of the video processing features research in computer systems and special purpose networks, it was found that in the maximum compression ratio is provided in B-type frames. However, such algorithms are the most resource intensive, which, in case of working with streaming, can lead to significant time delays in data transmission systems. The entire container of conversions is repeated in the reverse order.

2. Justification of the significance of predicted Pframes for processing motion images in the technology of compression of transformed images taking into account the fact that the possibilities for compressing the reference I-frames are limited, in consequence of the need to provide them with a sufficient level of quality, to further increase the level of the video data compression, we will consider in more detail the process of processing the transformed P-type frames.

\section{References}

1. Development of an advanced method of video information resource compression in navigation and traffic control systems / S. Yevseiev, Ahmed Abdalla, S. Osiievskyi, V. Larin, M. Lytvynenko // EUREKA: Physics and Engineering. - 2020. № 5. - P. 31-42. https://doi.org/10.21303/2461-4262.2020.001405.

2. Ruban I. Method of neural network recognition of ground-based air objects / I. Ruban, K. Smelyakov, N. Bolohova // Proceedings of 2018 IEEE 9th International Conference on Dependable Systems, Services and Technologies. - Kyiv, 24-27 May 2018. - P. 589-592. https://doi.org/10.1109/dessert.2018.8409200.

3. Sumtsov D. Development of a method for the experimental estimation of multimedia data flow rate in a computer network / D. Sumtsov, S. Osiievskyi, V. Lebediev // Eastern-European Journal of Enterprise Technologies. - 2018. - № 2(92). P. 56-64. https://doi.org/10.15587/1729-4061.2018.128045.

4. Network traffic measurement and analysis / D. Mistry, P. Modi, K. Deokule, A. Patel, H. Patki, O. Abuzaghleh // IEEE Long Island Systems, Applications and Technology Conference (LISAT). - Farmingdale, 29-29 April 2016. https://doi.org/10.1109/LISAT.2016.7494141.

5. The Problem of Big Data Transmission in the Mobile "Multi-Copter - Sensor Network" System / V. Tkachov, V. Tokariev, V. Radchenko, V. Lebediev // Control, Navigation and Communication Systems. - 2017. - № 2. - P. 154-157.

6. Hybrid model of knowledge for situation recognition in airspace / M. Pavlenko, A. Timochko, N. Korolyuk, M. Gusak // Automatic Control and Computer Sciences. - 2014. - № 5(48). - P. 257-263.

7. Gonzales R.C. Digital image processing / R.C. Gonzales, R.E. Woods. - New Jersey: Prentice Inc., 2002. -779 p.

8. Прэтт У. Цифровая обработка изображений: в 2 т.; пер. с англ. / У. Прэтт. - М.: Мир, 1985. - 736 с.

9. Миано Дж. Форматы и алгоритмы сжатия изображений в действии; пер. с англ. / Дж. Миано. - М.: Триумф, 2003. $-336 \mathrm{c}$.

10. Системи передавання даних / М.В. Захарченко, М.М. Гаджиєв, В.Є. Басов, О.М. Мартинова та ін. - О.: “Фенікс", 2009. - 406 с.

11. Korchynskii V.V. The increase of transmission protection based on multiplexing of timer signal constructions / V.V. Korchynskii, V.I. Kildishev, E.A. Osadchuk // Збірник наукових праць Одеської національної академії зв'язку. 2018. - № 1. - P. 93-97.

12. Захарченко Н.В. Увеличение информационной емкости найквистового элемента при передаче 2-х символьных ансамблей таймерными сигналами / Н.В. Захарченко, В.В. Гордейчук, Е.А. Севастеев // Сучасні інформаційні технології у сфері безпеки та оборони. - 2016. - № 2(26). - С. 21-26.

13. Conceptual Basis of Cascading Differential Masking Technology / M. Pavlenko, M. Kolmykov, O. Tymochko, S. Khmelevskiy, V. Larin // IEEE 11th International Conference on Dependable Systems, Services and Technologies (DESSERT). - Kyiv, 14-18 May 2020. - P. 43-50. https://doi.org/10.1109/dessert50317.2020.9125024.

14. General Approach to Counter Unmanned Aerial Vehicles / V. Tyurin, O. Martyniuk, V. Mirnenko, P. Open'ko, I. Korenivska // IEEE 5th International Conference Actual Problems of Unmanned Aerial Vehicles Developments (APUAVD). Kyiv, 22-24 October 2019. - P. 32-36. https://doi.org/10.1109/apuavd47061.2019.8943859. 


\section{Відомості про авторів:}

\section{Шевяков Юрій Іванович}

доктор технічних наук доцент директор Інституту цивільної авіації

Харківського національного університету

Повітряних Сил ім. I. Кожедуба,

Харків, Україна

https://orcid.org/0000-0002-5322-6674

\section{Ларін Володимир Валерійович}

кандидат технічних наук

доцент

Харківського національного університету

Повітряних Сил ім. І. Кожедуба,

Харків, Україна

https://orcid.org/0000-0003-0771-2660

Казаков Свген Леонідович

доктор технічних наук професор

професор

Льотної академії

Національного авіаційного університету,

Кропивницький, Україна

https://orcid.org/0000-0003-3558-9903

\section{Абдалла Ахмед}

аспірант

Льотної академії

Національного авіаційного університету, Кропивницький, Україна

https://orcid.org/0000-0001-9830-9548
Information about the authors:

Iurii Sheviakov

Doctor of Technical Sciences Associated Professor

Director of the Civil Aviation Institute

of Ivan Kozhedub Kharkiv

National Air Force University,

Kharkiv, Ukraine

https://orcid.org/0000-0002-5322-6674

\author{
Volodymyr Larin \\ Doctor of Philosophy \\ Associate Professor \\ of Ivan Kozhedub Kharkiv \\ National Air Force University, \\ Kharkiv, Ukraine \\ https://orcid.org/0000-0003-0771-2660
}

Eugene Kazakov

Doctor of Technical Sciences Professor

Professor

of Flying Academy

of the National Aviation University,

Kropyvnytskyy, Ukraine

https://orcid.org/0000-0003-3558-9903

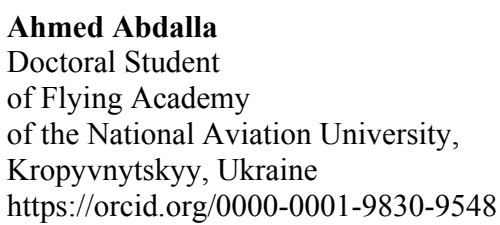

\section{ОСОБЛИВОСТІ ОБРОБКИ ВІДЕОІНФОРМАЦІЙНОГО РЕСУРСУ В КОМП'ЮТЕРНИХ СИСТЕМАХ ТА МЕРЕЖАХ СПЕЦІАЛЬНОГО ПРИЗНАЧЕННЯ}

Ю.І. Шевяков, В.В. Ларін, Є.Л. Казаков, Ахмед Абдалла

Для типової відеопослідовності низької складності вага кожного Р-кадру в поточі приблизно втричі мениа, ніж вага І-кадру. Однак, враховуючи кількість Р-кадрів у групі, вони вносять основний внесок у загальний обсяг відеоданих. Отже, розглядається можливість оновлення методів кодування для Р-кадрів при ідентифікації типу попередніх блоків з подальшим формуванням структур блокових кодів. Зі збільшенням коефіцієнта кореляції між сусідніми кадрами коефічієнт компресії двійкової маски поданого диференційного кадру збільшується. Коефіцієнт компресії двійкової маски поданого диференціалу варіюється від 3 до 21 залежно від коефіцієнта кореляції між сусідніми кадрами. Найбільш кращзи методом побудови технології компактного подання бінарних масок кадрів, які подані у диференційній формі, є підхід з урахуванням необхідності обробки поданого ресурсу на джерелі інформації. Це базується на ідентифікації та описі довжин одновимірних двійкових рядів. Двійковим рядом є задана послідовність двійкових елементів з однаковим значенням. У иььму випадку послідовності однакових двійкових елементів замінюються їх довжинами. Для подальшоі модернізації методів кодування та управління, в першу чергу визначено тип кадрів, щуо найбільше впливає на підсумковий обсяг обробленої відеопослідовності. Для цъього проведено порівняльну оцінку механізму обробки всіх типів кадрів. Обтрунтовано вибір прогнозованих Р-кадрів для удосконалення методів обробки через їх значний вплив на ступінь компресії відеоінформації. Щодо опорних кадрів обсяг переданих даних у Р-кадрі зменшується в середньому в 2-3 рази. Тому, чим більша кількість Р-кадрів використовується в відеопослідовності, тим сильніша компресія в иілому, але гірша якість зображення. Відповідно, вищчим повинен бути рівень контролю за помилками через те, шзо помилка в одному блоці пошириться на всю групу наступних Р-кадрів.

Ключові слова: зображення, компресія, кадр, елемент, рівень, надмірність, технологія.

\section{ОСОБЕННОСТИ ОБРАБОТКИ ВИДЕОИНФОРМАЦИОННОГО РЕСУРСА В КОМПЬЮТЕРНЫХ СИСТЕМАХ И СЕТЯХ СПЕЦИАЛЬНОГО НАЗНАЧЕНИЯ}

Ю.И. Шевяков, В.В. Ларин, Е.Л. Казаков, Ахмед Абдалла

Для типичной видеопоследовательности низкой сложности вес каждого І-кадра в потоке примерно в три раза больше веса P -кадра. Однако, учитьввая количество Р-кадров в группе из-за того, что они вносят основной вклад в обший объем видеоданных. По мере увеличения коэффициента корреляции между соседними кадрами степень сжатия двоичной маски дифференциально-представленного кадра увеличивается. Таким образом, рассматривается возможность модернизации методов кодирования Р-кадров при предварительной идентификации типов блоков с последуюшим формированием структур блочного кода для применения в компьютерных системах и сетях специального назначения.

Ключевые слова: изображение, сжатие, кадр, элемент, уровень, избыточность, технология. 